\title{
Genetiivi tšeremissin sijasysteemissä ${ }^{1}$
}

Taivutusmuotojen moninaisuutta pidetään suomalais-ugrilaisille kielille tunnusomaisena. Nominitaivutuksen osalta tämä ilmenee nimenomaan sijojen runsaslukuisuutena. Unkarin kielessä on tunnetusti kaksikymmentäneljä sijaa, syrjäänissä seitsemäntoista, suomessa neljä_viisitoista. Mutta toisaalta Norjan lappi tulee toimeen seitsemällä sijamuodolla, eikä pohjoisostjakista, nominatiivi mukaan luettuna, niitä mainita kuin kolme. Pikemminkin voisi sanoa, että näiden kielten ilmaisutarpeet tyydytetään sijapäätteiden avulla, jotka ilmaisevat erilaisia syntaktisia ja semanttisia vivahteita. Postpositiot, joita kaikkialla esïntyy varsin runsaslukuisesti, eivät sinänsä vastaa eivätkä täydennä sijamuotoja. Postpositiot eivät itsessään ilmaise kieliopillisia suhteita: syntaktinen funktio ilmenee postpositioon liittyvästä sijapäätteestä. Täten sijasysteemiin tulevat vedetyiksi myös epäproduktiiviset sijapäätteet: suomessa talon taa -rakenteen funktio ilmenee postposition latiivi-muodosta, joka on syntaktisesti yhtä merkitsevä kuin taloon-ilmauksen illatiivisuus.

Tǐ̌eremississä sijojen lukumäärä vaihtelee eri tutkijoilla huomattavasti. Wichmann löytää tšeremissille kokonaista kolmetoista sijamuotoa, kun taas nykykieliopit mainitsevat niitä neljä tai seitsemän, nominin merkityksen mukaan. Mainittakoon, etteivät Wichmannin luetteloon sisälly obsoliitit sijamuodot, joita tšeremississä on ainakin neljä.

Usein on vaikeaa ratkaista, mitkä muodot yleensä ovat sijamuotoja. Postposition ja sijapäätteen raja on häilyvä, ja useat sijat ovatkin syntyneet postpositiorakenteista. Itämerensuomalaisissa kielissä tästä on runsaasti esimerkkejä, lähinnä viron komitatiivi -ga:

1 19. 3. 1966 pidetty lectio praecursoria. 
pojaga-sijamuotoa vastaa suomessa postpositiorakenne pojan lkanssa. Wichmann erottaa tšeremississä gač-päätteisen elatiivin; nykykieliopit käsittävät tämän aineksen postpositioksi. Kun ottaa huomioon, ettei gəč ole mukautunut läntisten murteiden vokaalisointusysteemiin ja että sen edellä saattaa esiintyä pronominin ja nomininkin genetiivimuoto, viimeksi mainittua käsitystä voi hyvin puolustaa.

Toisaalta myös sijapääte ja johdinsuffiksi saattavat olla lähellä toisiaan. Suomen muotoja maitse, meritse tai asteittain, laseittain ei käsitetä sijamuodoiksi vaan adverbeiksi, koska niihin ei voi liittää adjektiiviattribuuttia, ei sanota *launïtse maitse. Kielissä, missä adjektiiviattribuutti ei kongruoi, saattaa olla vaikea tehdä ero sijamuodon ja adjektiivijohtimen välille. Wichmann erottaa tšeremississä -laloppuisen modaali-sijan, joka tosin rajoittuu vain muutamiin sanoihin ja sanontatapoihin: marla ojlaš 'puhua tšeremissiksi', totarla ojlaš 'puhua tataariksi'. Sama suffiksi liittyy myös verbaalinominiin ilmaisten samanaikaista tekemistä: kajšažla užən 'kävellessään hän näki'. Mutta toisaalta muoto saattaa esiintyä attribuuttina: totarla šolək 'tataarilaishuivi', eikä se käytettävissä olevissa lähteissä koskaan itse sáa adjektiiviattribuuttia: * saj marla ojlaš 'puhua hyvää tšeremissiä' on mahdoton. Loppuliitteet eli enkliitit, joita suomen kieliopissa sanotaan liitännäispartikkeleiksi, voivat myös sekaantua sijapäätteisiin. Tästäkin on Wichmannin sijaluettelossa esimerkki. Komitatiivisuffiksi ge esiintyy nimensä mukaisessa merkityksessä sellaisessa esi-

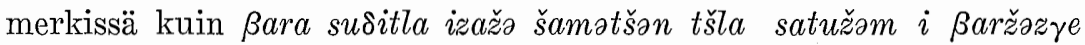
üžalaš 'sitten hän määrää vanhempien veljien koko omaisuuden, veneineen päivineen myytäväksi' (Jt F II 585). Mutta sama suffiksi saattaa liittyä mihin lauseen jäseneen tahansa, esim. subjektiin:

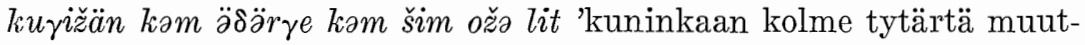
tuivat kolmeksi mustaksi oriiksi' (Rkb 179). ge-ainesta saattaisi pitää merkitykseltään inklusiivisena enkliittinä, vaikeutena on vain se, että se liittyy aina suoraan sanan vartaloon eikä suvaitse sanassa mitään sijapäätettä.

Inflektiosuffiksi ilmentää sanan syntaktista asemaa lauseessa. Suhteessa toisiinsa lauseenjäsenet saattavat olla joko rinnasteisia tai alisteisia tai niiden välillä vallitsee neksussuhde. Viimeksi mainittu käsite on Otto Jespersenin täsmentämä ja kehittämä, vaikka jo Adolf Noréen ja Kielioppikomitean lausunto puhuvat neksuksesta eli jaksosta. Neksus vallitsee lauseenjäsenten kesken, jotka eivät ole toi- 
silleen rinnasteisia sen paremmin kuin alisteisiakaan ja joiden syntaktinen funktio on toinen kuin koko neksuksen funktio. Tyypillinen neksus on todettavissa lauseen kahden pääjäsenen, subjektin ja predikaatin, välillä, mutta neksus saattaa kehittyä jopa kahden nomininkin väliin. Rinnasteisuutta ilmentävät lauseasema, sama taivutuspääte, yhteinen pääsana, alisteisuutta taas lauseasema ja eri taivutuspääte. Alisteiset lauseenjäsenet eli määritteet voidaan jakaa kahteen ryhmään: adnominaalisiin ja adverbaalisiin.

Vaikka suomalais-ugrilaisissa kielissä verbi ja nomini eivät muodostakaan yhtä selvästi toisistaan erottuvia kategorioita kuin esim. indo-eurooppalaisissa, voidaan tšeremississä vartalot todeta joko verbeiksi tai nomineiksi niihin liittyvien taivutuspäätteiden avulla. Sijasysteemin rungon muodostavat kieliopilliset sijat, jotka eivät osoita muuta kuin syntaktisia suhteita. Karkeasti jaotellen voidaan nominatiivi selittää neksuksen primaarijäsenen sijamuodoksi, genetiivi taas yleisen adnominaalisen ja akkusatiivi yleisen adverbaalisen määritteen muodoksi. Grammatikaalinen ilmaisutarve tulee siis tyydytetyksi jo näiden kolmen sijamuodon avulla.

Tosiasiassa tilanne ei kuitenkaan ole näin yksinkertainen. Selvin asema on akkusatiivilla, joka tšeremississä - poikkeuksena muista suomalais-volgalaisista kielistä etelälappia lukuun ottamatta - on säilyttänyt alkuperäisen sananloppuisen $-m: n$ ja säästynyt sekoittumasta esim. genetiiviin. Akkusatiivi on yksinomaisesti verbin määritteen sijamuoto. Nominatiivi on taas yleismuoto, joka voi esiintyä kaikissa edellä mainituissa funktioissa: verbin tekijänä, adnominaalisena ja adverbaalisena määritteenä. Esimerkiksi sopii seuraava Ja-ranskin murretta edustava lause: pərəs užən maska rok tarßaltəməm 'kissa näki karhun kiven vyöryttämisen', ts. kissa näki karhun vierittävän kiveä' (Bj b 278). Ensimmäinen nominatiivi parəs on lauseessa subjektina, siis neksussuhteessa predikaattiverbiin. Toinen nominatiivi maska voitaisiin korvata genetiivillä ja kolmas, rok, akkusatiivilla. Näyttää siltä, että sekä genetiivi että akkusatiivi ovat sijamuotoina tarpeettomat. Akkusatiivi on kuitenkin objektin sijana nominatiivia yleisempi, varsinkin finiittiverbin ohessa ja verbaalinomininkin määritteenä silloin kun objektinominiin liittyy jokin oma määrite.

Genetiivin laita on toisin. Jo yksistään se seikka, että genetiivi on tšeremississä melko harvinainen sijamuoto, vaikuttaa oireelliselta. 
Adnominaalinen genetiivi esiintyy varsinaisesti vain kahdessa tapauksessa: silloin kun adnominaalisena määritesanana on pronomini ja silloin kun siinä asemassa on elollista tai personifioitunutta käsitettä ilmaiseva nomini. Sitä paitsi genetiivikonstruktioihin kuuluu olennaisesti pääsanaan liittyvä ja määritteeseen viittaava persoonantunnus eli possessiivisuffiksi. Nominatiivin ja genetiivin välillä ei kuitenkaan vallitse täydentävää jakaumaa. Ainoastaan käytettynä kolmannen persoonan ja useimmișsa murteissa myös monikon ensimmäisen ja toisen persoonan pronomineista genetiivi on omalla erikoisalallaan lähes yksinomainen; muissa tapauksissa nominatiivi on melkein yhtä yleinen. Yksikön ensimmäisen ja toisen persoonan osalta on vaihtoehtona pronominin nominatiivi ja pääsanaan liittyvä vastaava persoonantunnus, nominin osalta - elollisen yhtä hyvin kuin elottomankin - välittömästi pääsanaansa edeltävä nominatiivimuoto, persoonantunnus suhdetta vahvistavana on harvinainen. Tämä selviää esim. seuraavasta lauseesta: ̌̌em šorəkən jolžə tängäl tolěs kən,

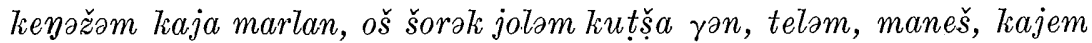
marlan 'jos käteen sattuu mustan lampaan jalka, tyttö menee kesällä naimisiin, jos hän tarttuu valkoisen lampaan jalkaan: talvella, hän sanoo, menen miehelään' (Bb 2 350). Jalka saa genetiivimääritteen, kun kyseessä on musta lammas, mutta nominatiivimääritteen silloin kun puhutaan valkoisesta lampaasta, mikä osoittaa että nominatiivin tai genetiivin esiintyminen on aivan mielivaltaista.

Välitön adnominaalinen määrite on itse lauseenrakenteen kannalta merkityksetön. Sen syntaktinen asema on kokonaan riippuvainen pääsanasta, joten pääsanan asemassa tapahtuvat muutokset voivat vaikuttaa myös määritteeseen. Näin on laita silloin kun pääsanan paikalla on postpositio tai verbaalinomini. Postpositiorakenteessa määrite on välttämätön osa ja itse postpositio vain välittävä aines, jonka avulla sijapääte nivoutuu konstruktioon. Suhteen kiinteyttä korostaa sekin, että nominatiivi on postpositiorakenteen jäsenenä melkein yksinomainen; vain pronominien osalta tulee genetiivi kyseeseen.

Myös verbaalinominiin saattaa liittyä nominatiivi- tai genetiiviasuinen määrite. Milloin verbaalinomini esiintyy lauseenvastikkeena, siis päälauseen määritteenä, sen yhteydessä oleva nominatiivi tai genetiivi on tulkittavissa verbaalinominin tekijäksi. Nominin ja verbaalinominin välillä vallitsee neksussuhde tai ainakin neksukseen 
viittaava suhde. Nominatiivi ja genetiivi esiintyvät rinnan verbaalinominin tekijöinä, kuten yleensä nominin määritteinäkin, mikä ilmenee

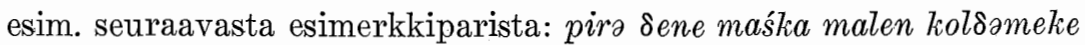

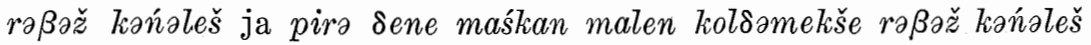
'suden ja karhun nukahdettua kettu nousee' (Bt 498). Esimerkit ovat samasta Tsarevokoksajskin murretta edustavasta tekstilähteestä, vieläpä samalta sivulta; toisessa on tekijänä nominatiivi maśka ja verbaalinomini on vailla persoonantunnusta, toisessa tekijää ilmaisee genetiivimuoto maśkan ja verbaalinominiin liittyvä persoonantunnus.

Nominatiivi ja persoonantunnus näköjään rịittävät täyttämään välittömän adnominaalisen genetiivin funktiot. Mutta on tapauksia, jolloin genetiiviä ei voi korvata nominatiivilla, vaan vertailukohdaksi on otettava paikallissijasysteemi.

Suomalais-ugrilaisille kielille on ominaista paikallisilmausten kolmitahoisuus. Verbin toiminta todetaan joko paikallaan pysyvänä, jolloin siihen liittyy olosijamäärite, tai pisteestä toiseen suuntautuvana liikkeenä, jota ero- ja tulosijat ilmaisevat. Erikoisen selvästi tämä on havaittavissa suomen kielessä, jossa voidaan erottaa kolme kolmisijaista ryhmää: yleiset, sisäiset ja ulkoiset paikallissijat. Tšeremississä ei järjestelmä ole lainkaan yhtä symmetrinen. Yleisiä paikallissijoja edustavat lokatiivi-, elatiivi- ja latiivimuodot ovat tosin löydettävissä postpositioina ja adverbeina, mutta sekä sisäisten että ulkoisten paikallissijojen suhteen on poikkeavuutta. Tšeremississä on kyllä produktiivinen olosija, inessiivi, ja kaksi tulosijaa: latiivi ja illatiivi, mutta erosijan ilmaisee postposition välityksellä vanha elatiivisuffiksi -č. Etymologisesti suomen ulkoisia paikallissijoja vastaavia muotoja mainitaan kieliopeissa vain yksi, tulosija datiivi, jonka päätteenä on lan, mutta murteittain esiintyy myös leč-loppuinen erosija, jota voi verrata suomen ablatiiviin. Olosijasta sitä vastoin ei ole jälkeäkään. Tšeremississä ei myöskään ole sisäisten ja ulkoisten paikallissijojen vastakohtaa. Datiivi lan ja ablatiivi leč ovat varsinaisesti vain elollisista käsitteistä käytettäviä muotoja ja ilmaisevat henkilön, johon verbin toiminta suuntautuu. Suomessakin ulkoisilla paikallissijoilla ilmaistaan omistussuhdetta: Heillä on lapsi, Heiltä kuoli lapsi, Heille syntyi lapsi. Jos persoonapronominin sijaan pannaan "eloton" nomini, vaikkapa talo, verbin toiminnan suunta ilmaistaan sisäisten paikallissijojen avulla: Talossa on lapsi, Talosta kuoli lapsi, Taloon syntyi lapsi. Suomen ulkoiset paikallissijat kattavat 
kuitenkin käsitteellisesti paljon laajemman alan kuin mainitut tšeremissin sijamuodot. Kun tšeremississä datiivi ja ablatiivi rajoittuvat ilmaisemaan possessiivista suhdetta, on johdonmukaista, että ne saavat systeemin täydentäjäksi kolmannen elollisista käsitteistä käytettävän sijamuodon eli genetiivin. Genetiivi vastaa suomen olosijaa sellaisissa ilmauksissa kuin nunən kok üdəržö ulo 'heillä on kaksi tytärtä' (Jwb), mutta se voi yhtä hyvin korvautua ablatiivilla tai allatiivilla: miñan tuje iš lek 'minulta se ei käynyt samoin' (Bu 1 97) tai tudən ikšəbe šočən ogal 'hänelle ei syntynyt lasta' (Jwb). Voidaan siis todeta, että tšeremisssissä genetiivi ilmaisee henkilöä, johon verbin toiminta suuntautuu. Välillisten possessiivisten suhteiden kategoriassa se korvaa olosijan, mutta samalla se korvaa ero- ja tulosijat yhtä hyvin; jälkimmäisessä tapauksessa vain ovat vaihtoehtoisesti tarjona suuntaa ilmaisevat ablatiivi ja datiivi.

Vastaavanlainen genetiivi esiintyy myös lauseissa, joissa predi-

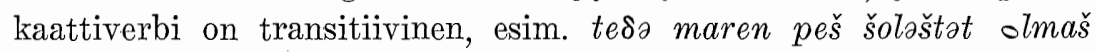
müm 'tältä mieheltä oli varastettu paljon hunajaa' (Bjb 54). Toisinaan, varsinkin läntisissä murteissa, genetiiviin saattaa liittyä akkusatiivin pääte: məńənəm kü oksam šoləštən? 'kuka on varastanut minulta rahaa?' (Bj a 70). Eräissä esimerkeissä genetiivin paikalla on akkusatiivi: te šoləštən olsa kot'am oksam 'te olette varastaneet isoisän rahat' (Bj b 103). On ilmeistä, että genetiivi tällaisissa tapauksissa esiintyy epäsuorana objektina. Datiivi ja ablatiivi ja postpositiorakenteet ovat kuitenkin mainitussa funktiossa sekä genetiiviä että akkusatiivia paljon tavallisemmat.

Vaikka genetiivi eräissä tapauksissa korvautuu paikallissijoilla, sitä ei varsinaisesti voi lukea niihin kuuluvaksi. Se on yhä olennaisesti adnominaalinen sijamuoto, joka on alkanut irtaantua nominista ja hakeutua verbin yhteyteen. Adnominaalisuuteen viittaa se, että tällaisen välillisenkin genetiivin pääsanaan useimmiten liittyy genetiiviin viittaava persoonantunnus. Genetiivi ja persoonantunnus esiintyvät yleisesti toisiaan vastaavissa tai toisiaan täydentävissä funktioissa; niinpä pelkkä persoonantunnus voi genetiivin tavoin struktu-

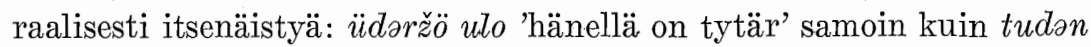

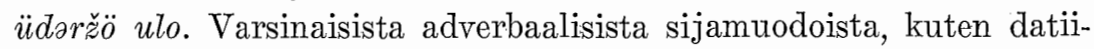
vista ja ablatiivista, ilmenee verbin tekemisen suunta, genetiivi on tässä suhteessa aivan neutraali. Välillinen adnominaalinen genetiivi ilmaisee intransitiivilauseessa henkilöä, jota subjektin toiminta koskee, 
transitiiviverbin sisältävässä lauseessa taas henkilöä, jota objektin toimintaan saattaminen koskee.

Kieliopillisten sijojen ja verbin toiminnan suuntaa ilmaisevien paikallissijojen ohella kaasussysteemiin kuuluu vielä joukko marginaalisia sijamuotoja, jotka jotenkin modifioivat verbin toimintaa. Tšeremissin adverbaalisessa genetiivissä ilmenee useita adnomisaumattomasti sovellu systeemiin, kuten edellä on viitattu, sekä suomen abessiivia vastaava karitiivi. Lisäksi kaikki muut sijamuodot, kieliopilliset yhtä hyvin kuin paikallissijatkin, saattavat esiintyä verbin vapaina määritteinä. Genetiivi on tässä asemassa hyvin tavallinen. Wichmann pitää sitä itsenäisenä instruktiivisijana, mutta Wiklundin ja Ravilan tutkimukset ovat osoittaneet, että genetiivin ja instruktiivin ero on vain erilaisessa syntaktisessa distribuutiossa. Tšeremissin adverbaalisessa genetiivissä ilmenee useita adnominaaliselle genetiiville vieraita piirteitä. Adnominaalinen genetiivi, sekä välitön että välillinen, rajoittuu persoonallisia käsitteitä merkitseviin sanoihin, adverbaalinen genetiivi on täysin rajoittamaton. Kaikki kielen sanat, persoonapronomineja lukuun ottamatta, saattavat esiintyä adverbaalisina genetiiveinä, vieläpä adjektiivitkin. Muodon merkitystä on mahdotonta täsmentää. Se on milloin modaalinen, milloin instrumentaalinen, milloin temporaalinen; asia riippuu asianomaisen sanan leksikaalisesta merkityksestä tai sen syntaktisen suhteen kiinteydestä. Paitsi verbiin adverbaalinen genetiivi saattaa liittyä koko neksussuhteeseen. imńən kaja on tämän mukaisesti milloin 'menee hevosella', milloin 'menee hevosena'.

Eräissä yhteyksissä adverbaalinen genetiivi on kehittynyt verbin sidonnaiseksi määritteeksi. Se saattaa esiintyä predikatiivisessa funktiossa paikallissijan tavoin. Beken Kozmodemianskin murretta edustavassa kokoelmassa (Bkb) latiivi ja genetiivi esiintyvät aivan vastaavissa ilmaisuissa: kəška ləštəkěs (latiivi s. 230) ja kəška ləštəkən (genetiivi, s. 227), merkitys on sama: 'hän leikkaa kappaleiksi'. Eräiden verbien yhteydessä genetiivi on predikatiiviadverbiaalin sijana yleisin: kojam 'näyttää', čučam 'tuntua', esim. imńən koješ 'näyttää hevoselta'; vaihtoehtoina ovat modaali tai nominatiivi.

Kuten näkyy, genetiivi on lonkeroitunut tšeremissin sijasysteemin kaikkiin osiin. Se esiintyy ensinnäkin välittömänä adnominaalisena sỉjamuotona, jolloin se korvautuu nominatiivilla. Venbaalinominin yhteydessä se on kehittynyt tai ainakin on kehittymässä neksussuhteen 
primäärijäseneksi. Välillinen adnominaalinen genetiivi on nivoutunut paikallissijasysteemiin. Se ilmaisee henkilöä, jota verbin toiminta koskee, ja voi korvata tekemisen suunnan ilmaisemiseen erikoistuneet sijamuodot ablatiivin ja datiivin. Transitiiviverbin finiittimuodolle rakentuvassa lauseessa genetiivi voi ilmaista välillistä objektia. Adverbaalinen genetiivi esiintyy verbin sidonnaisena määritteenä predikatiivista suhdetta ilmaisemassa, ja sen paikalla saattaa olla nominatiivi tai predikatiivista suhdetta ilmaiseva tulosija latiivi. Lisäksi se esiintyy verbin vapaana määritteenä mitä moninaisimmissa merkitysvivahteissa ja koko neksuksen määritteenä. Myös adverbaalinen genetiivi saattaa kehittyä neksussuhteen primaarijäseneksi, vrt. distributiivisen lukusanan käyttöä subjektina, minkä nykykieliopitkin mainitsevat: koktan kajat 'he menevät kahden' on tullut merkitsemään 'he kaksi menevät'. Selväksi subjektiksi muoto on tulkittava esim. seuraavassa lauseessa: koktənžə ulməžə ǔ̆an 'he kaksi olivat viisaita' (Bu 1 457).

Vaikka tšeremississä genetiivi ei muodon puolesta voi sekaantua muihin sijoihin, sen funktiot osoittavat, että se on tavallaan sittenkin erikoistumaton, yleinen alisteista suhdetta ilmaiseva muoto. Oikeastaan ainoa ala, minne genetiivi ei ole tunkeutunut, on varsinainen lokaalinen funktio, jossa tekemisen suunnan ilmaiseminen on kehittynyt ensiarvoiseksi merkitystekijäksi. On ymmärrettävää, ettei genetiivin kaltainen yleinen sijamuoto ole pystynyt lokaalista funktiota kannattamaan.

\section{Lähteiden lyhenteet}

Rkb = Ramstedt, G. J., Bergtscheremissische Sprachstudien. SUST 17.

$\mathrm{Bkb}=\mathrm{Beke}$, Ödön, A cseremiszek (marik) népköltészete és szókásai 1.

Bj a = Beke, ödön, Tscheremissische Texte zur Religion und Volkskunde.

$\mathrm{Bj}$ b = Beke, ödön, Mari szövegek, I kötet, ss. 6-35i.

Bu $1=$ Beke, ödön, Tscheremissische Märchen, Sagen und Erzählungen. SUST 76.

Bt $=$ Beke, ödön, Mari szövegek, I kötet, ss. 364-552.

$\mathrm{Jt}=$ Jevsevjevin kokoelma.

Bb 2 = Beke, ödön, Mari szövegek, IV kötet, ss. 153-447.

$\mathrm{J}_{\mathrm{wb}}=\mathrm{Iwan}$ Jewskijltä saatu aineisto. 


\section{Enva KangasmaA-Minn: The position of the genitive in the Che- remis case system}

Diversity of inflectional forms is generally considered to be characteristic of the Finno-Ugric languages. In several of them the number of the case forms is, however, surprisingly small. The number of the case suffixes is not decisive; the essential question is how far these elements are used in different syntactic and semantic functions.

The number of the Cheremis ease forms varies greatly in different sources. Wichmann finds as many as thirteen, the present grammars give only four or seven, depending on the meaning of the word in question. An inflection suffix designates the syntactical position of the word. Nominative, accusative and genitive are grammatical case forms - they have no actual "meaning". The nominative is primarily the ease form of the subject or the adnominal modifier. The accusative is the form of the object. The functions of the genitive are not easily discernible.

The adnominal genitive is a relatively rare syntactic eategory. It is actually found in only two eases: when the adnominal adjunct is a pronoun or when it is a noun designating an animate conception. There is, however, no complementary distribution between the genitive and the other adnominal case form, the nominative. Only used with respect of pronouns the genitive is almost nonexceptional, the nominative is almost as frequently used with respect of animate nouns: śem šorakan jolže 'a black sheep's leg' (genetive; oš šorək jol 'white sheep leg' (nominative). Thus the adnominal genitive seems a more or less unnecessary syntactic category.

In some instances, however, the genitive cannot be replaced by the nominative, but by the local case forms. Finno-Ugric languages have a three-dimensional system of local cases. The action of the verb is specified as static, which is shown in an adverbial which takes the form of an in-case, or as moving from one point to another, which is indicated by adverbials in from- or into-cases. This system is especially clear in Finnish, which has three groups of threedimensional local cases. Cheremis is not at all as well organized. It has a productive in-case: the inessive, and two into-cases: the lative and the illative, but the from-case is indicated, with the help of postpositions, by an obsolete elative suffix. Etymological counterparts for the Finnish outer local cases are the dative in lan and the ablative in leč. There is no trace of an in-case, corresponding to the adessive in Finnish. There is no contrast between inner and outer local cases, either. Even in Finnish the outer local cases may indicate possession: Heillä on lapsi 'They have a child.' Heiltä kuoli lapsi 'They lost a child.' Heille syntyi lapsi 'A child was born to them.' The Cheremis dative and ablative are limited to expressing possessive relations and they, like the adnominal genitive, are limited to words designating animate conceptions. To complete

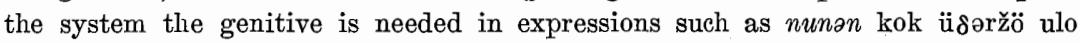
'They have two daughters' where it corresponds to the adessive in Finnish. But it may also correspond to the Finnish ablative and allative: minan tuye iš lek 
'I. didn't succeed in the same way', or tudən ikšəbe šočən ogəl 'He didn't have any children.' In Cheremis the geuitive indicates the person who is affected by the action of the verb. If the predicate is a transitive verb, the genitive designates the indirect object.

In addition to the grammatical and local cases, the Cheremis declensional system contains a number of marginal case forms, which modify the action of the verb. All the case forms may occasionally occur as free adverbial modifiers. The genitive is very common in this function. As an adverbial, the use of the genitive knows no restrictions. All the words in the language, even the verbs and the adjectives, may occur as adverbial genitives. The form as such has no meaning. It is sometimes modal, sometimes instrumental, sometimes temporal depending on the lexical meaning and/or the degree of syntactic freedom of the word. In addition to occurring as a modifier of the verb, the adverbial genitive may act as an adjunct to the whole nexus relation: imnan kaja might mean both 'Goes by horse' or 'Goes as a horse.'

The diversity of the functions of the Cheremis genitive indicates that the case form is an unspecified syntactic category designating a general dependent relation from another syntactic unit. The only field untouched by the use of the genitive is the proper locational relation, where the direction of the action has developed into a primary semantic factor. 